\title{
The water absorbability of beech (Fagus sylvatica L.) and fir (Abies alba Mill.) organic matter in the forest floor
}

\author{
Anna Ilek ${ }^{1,2 \S}$, Małgorzata Szostek3 , Jarosław Kucza² , Jadwiga Stanek-Tarkowska³ \\ Wojciech Witek ${ }^{2}$
}

Ilek A., Szostek M., Kucza J., Stanek-Tarkowska J., Witek W., 2019. The water absorbability of beech (Fagus sylvatica L.) and fir (Abies alba Mill.) organic matter in the forest floor. Ann. For. Res. 62(1): 3-14.

Abstract. The organic horizons of forest soils are characterised by double capillarity: between particles and inside them. It has been hypothesized that the time required to fill the internal capillarity of organic particles depends on their botanical origin and the degree of their decomposition. The aim of the present study is to determine the time of water absorption by organic matter that is part of the $\mathrm{Ol}$ and Ofh horizons of selected beech (Fagus sylvatica L.) and fir (Abies alba Mill.) stands. The present research on water absorbability lasted for 14 days and consisted in measuring the absorption time in organic particles from the moment of immersion of an air-dry sample in water until the particles soaked in water exceeded the density of $1.0 \mathrm{~g} \cdot \mathrm{cm}^{-3}$. It was found that in fir organic matter the time of water absorption decreases with the advancement of decomposition. In beech stands, progressing decomposition processes result in a longer water absorption time. The dynamics of water absorption of organic matter indicates that no single rainfall is able to entirely fill the internal capillarity of organic particles, whereby the organic horizons of forest soils can maintain the ability to retain water even in long-term rainfall.

Keywords: forest hydrology, forest soils, water absorbability, organic matter, Fagus sylvatica L., Abies alba Mill.

Authors. 'Department of Forest Sites and Ecology, Faculty of Forestry, Poznań University of Life Sciences, ul. Wojska Polskiego 71F, 60-625 Poznań, Poland | ${ }^{2}$ Department of Soil Science, Environment Chemistry and Hydrology, University of Rzeszow, ul. Ćwiklińskiej 2/D3, 35-601 Rzeszow, Poland ${ }^{3}$ Department of Forest Engineering, Institute of Forest Ecosystem Protection, Faculty of Forestry, University of Agriculture in Krakow, Al. 29 Listopada 46, 31-425 Krakow, Poland. \$ Corresponding author: Anna Ilek (anna.ilek@up.poznan.pl)

Manuscript received January 4, 2019; revised May 3, 2019; accepted June 10, 2019; online first June13, 2019. 


\section{Introduction}

The process of rainfall infiltration through the forest environment into the soil was compared by Suliński (1993) to filling 4 containers: (i) the tree surface, (ii) the surface of plants of the forest floor, (iii) the forest litter horizon and (iiii) the capillary spaces in the mineral soil horizon. Each of these containers is characterised by a specific water storage capacity and a specific mechanism of filling, which can occur simultaneously or with a certain delay. As the highest soil horizon, the forest litter retains both rainwater and water flowing down the tree stem (Putuhena \& Cordery 1996). It has a positive effect on the water content in the near-surface soil horizon and keeps moisture in soil for longer periods after rainfall (Sharafatmandrad et al. 2010). Litter plays an important role in water infiltration into the soil profile, prevents erosion, slows down stemflow and limits evaporation from deeper soil horizons (Onda \& Yukawa 1994, Tamai et al. 1998, Greiffenhagen et al. 2006). Its water storage capacity depends not only on the quantitative share of individual litter components, such as leaves, needles and branches, but also on the bulk density, total porosity and species composition of the stand (Laurén \& Mannerkoski 2001, Zhang et al. 2006, 2009, Ilek et al. 2015, 2017).

In the water exchange between the atmosphere, the stand and the soil, an important role is played not only by litter but by entire organic soil horizons. Depending on the advancement of organic matter decomposition processes, apart from litter (Ol), consisting of less decomposed organic debris with preserved tissue structure, the following subhorizons are distinguished in the organic horizons of forest soils (Dziadowiec et al. 2004): (i) detritus (Ofh) - composed of highly fragmented and discoloured material as well as mineral particles, (ii) fermentation (Of) - composed of highly fragmented and discoloured material and (iii) epihumus (Oh) - containing mainly macro- and microscopically amorphous humus as well as a significant admixture of mineral material.

The organic horizons of forest soils are formed under the influence of vegetation and the processes of organic matter decomposition. They mainly include fallen leaves and needles as well as other dead parts of plant and animal origin. The thickness of organic horizons depends on climate, vegetation, topography, soil type and human activity (Walsh \& Voigt 1977). While in litter the water is retained mainly on the surface of its constituent organic particles, inside the tissues and in the spaces between individual particles (Suliński 1993), along with the advancement of organic matter decomposition and its fragmentation in the Of, $\mathrm{Oh}$ and Ofh horizons it is capillary spaces that play an increasingly greater role in retaining water. As soil horizons containing organic particles are characterised by double capillarity: between and inside particles (Kucza 2007), the dynamics of rainwater retention through these horizons is a complex process that is relatively poorly understood. Considering the influence of the species composition of a stand and the degree of organic matter decomposition on the physical and retention properties of the organic horizons of forest soils (Ilek et al. 2015, 2017), it is necessary to take into account the different time periods necessary to fill the internal capillarity of organic matter particles in various states of transformation. Therefore the present study inspects the hypo thesis that the filling of the internal capillarity of organic particles depends on their botanical origin and the degree of their decomposition. The aim of the present research is to determine: (i) the dynamics of water absorbability, (ii) the average time of water absorption and (iii) the minimum time required to fill with water the internal capillarity of organic matter that is part of the litter (Ol) and detritus (Ofh) horizons of selected beech (Fagus sylvatica L.) and fir (Abies alba Mill.) stands in southern Poland. 


\section{Materials and methods}

\section{Research area and sampling}

The research on the water absorbability of organic matter covered the Ol litter horizons and the Ofh detritus horizons in 9 beech stands and 10 fir stands, whose general characteristics are given in Table 1. The stands are located in the Złoty Potok catchment area and the Proszkowców stream catchment, located within the area of the Makowski Beskid Mts in southern Poland (Fig.1). The soils of all examined stands were classified as Dystric Cambisols (IUSS Working Group WRB 2015).

The research material was obtained in November 2014. In each of the stands, a transect with a length of $100 \mathrm{~m}$ was designated, where

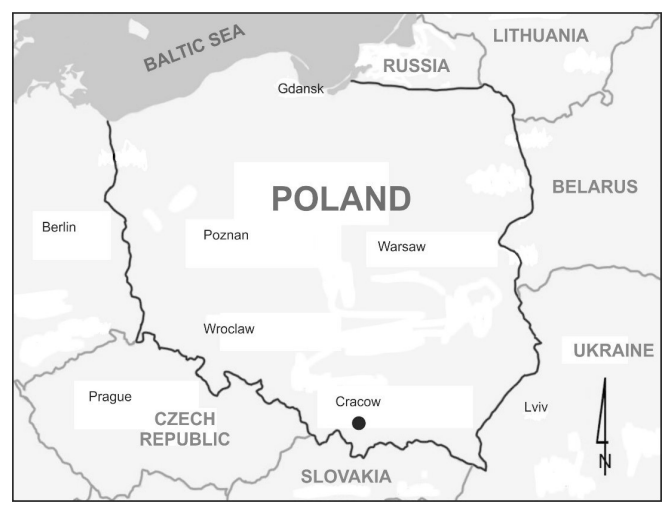

Figure 1 Location of the study area samples of $\mathrm{Ol}$ and $\mathrm{Ofh}$ horizons were collected at every $20 \mathrm{~m}$. Water absorbability and the degree of organic matter decomposition were tested using averaged samples, obtained as a result of mixing the material sampled from a given transect. In the case of $\mathrm{Ol}$ horizons in fir and beech stands, water absorbability was tested only in needles and leaves, as they constituted the largest part of the litterfall produced annually by these stands (Švidenko 1980, Małek 2006, Niewinna 2010, Jonczak 2013).

\section{Laboratory tasks}

When measuring the water absorbability of organic matter, it was assumed that the water-soaked organic particles reach the state of internal capillarity filling once their density exceeds $1.0 \mathrm{~g} \cdot \mathrm{cm}^{-3}$. This method of water absorbability measurement was adopted after Kucza \& Urbaś (2005) and Kucza (2007). It consists in measuring the soaking time of organic matter from the moment of immersion of an airdry sample in distilled water at $20^{\circ} \mathrm{C}\left( \pm 2^{\circ} \mathrm{C}\right)$, until the moment of its sinking to the bottom of the beaker, i.e. until the water-soaked particles exceed the density of $1.0 \mathrm{~g} \cdot \mathrm{cm}^{-3}$. The soaking time of the organic matter was examined for 14 days; the particles that had sunk to the bottom were removed at least once a day, dried at

Table 1 Basic characteristics of the sampling sites

\begin{tabular}{|c|c|c|c|}
\hline \multirow{2}{*}{ Characteristics } & \multirow{2}{*}{ Variable } & \multicolumn{2}{|c|}{ Vegetation type } \\
\hline & & Abies alba & Fagus sylvatica \\
\hline \multirow{3}{*}{ Topography } & Altitude $[\mathrm{m}]$ & $430-810$ & $520-765$ \\
\hline & Exposure & $\mathrm{N}, \mathrm{NW}, \mathrm{NE}$ & $\mathrm{S}, \mathrm{SW}, \mathrm{SE}$ \\
\hline & Slope $\left[{ }^{\circ}\right]$ & $10-22$ & $5-25$ \\
\hline \multirow{6}{*}{ Stand characteristics } & Age [years] & $30-120$ & $10-115$ \\
\hline & $\mathrm{DBH}[\mathrm{cm}]$ & $10-51$ & $24-102$ \\
\hline & Humus form & moder & moder \\
\hline & Height [m] & $8-31$ & $5-32$ \\
\hline & \multirow{2}{*}{ Thickness [cm] $\frac{\mathrm{Ol}}{\mathrm{Ofh}}$} & $0.2-1.0$ & $0.4-1.0$ \\
\hline & & $0.6-2.8$ & $0.6-3.4$ \\
\hline
\end{tabular}


$105^{\circ} \mathrm{C}$ and weighed. The removal of particles was accompanied by the exchange of water in the beakers. In the Ofh horizons, often containing a significant amount of mineral particles, the weight of individual fractions of a sample that had sunk to the beaker bottom after a given soaking time was reduced by the share of the weight of mineral particles by incinerating the samples at a temperature of $550^{\circ} \mathrm{C}$. For that reason, the results of the present research refer only to the organic matter present in these horizons. The calculation of the content of organic matter took into account the share of ash parts remaining in a given sample after incineration. The following relationships were used for the conversions: $100 \%$ of fir organic matter $=97.5 \%$ loss on ignition and $100 \%$ of beech organic matter $=96.6 \%$ loss on ignition (Ilek et al. 2015). The method of conducting the experiments made it possible to divide the organic matter contained in the $\mathrm{Ol}$ and Ofh horizons into: (i) sinkable matter, capable of reaching a density greater than $1.0 \mathrm{~g} \cdot \mathrm{cm}^{-3}$, and (ii) unsinkable matter, unable to achieve the desired absorbability even after 14 days of soaking.

The mean time $T_{A}$ of water absorption by the organic matter from the $\mathrm{Ol}$ and $\mathrm{Ofh}$ horizons of the beech and fir stands was calculated as the weighted average mass of particles that had sunk to the bottom after a given soaking time, in relation to the total weight of the particles sinkable in water.

The minimum time $\left(t_{\min }\right)$ needed to fill the internal capillarity of the sinkable organic matter being part of the $\mathrm{Ol}$ and Ofh horizons as well as the entire organic horizons $\mathrm{O}$ was determined on the basis of the cumulative percentage of organic particles that sank after a given soaking time. This percentage was determined jointly for all samples from individual horizons of the fir stands and for all samples obtained from the beech stands. The time after which $75 \%$ of the organic matter from a given horizon reaches a density greater than $1.0 \mathrm{~g} \cdot \mathrm{cm}^{-3}$ was adopted as the moment of filling the internal capillarity.

The content of organic carbon $C$ in individ- ual soil horizons was determined by the Tiurin method while the total content of nitrogen $N$ was determined by the Kjeldahl method in the Kiej-Fos automatic 16210 kit. The degree of decomposition was expressed using the decomposition index of organic matter $W_{N C}$ in the following form (Kucza \& Urbaś 2005):

$W_{N C}=1000 \cdot(N / C)$

\section{Results}

\section{The share of unsinkable organic matter}

The distribution of variability of the percentage of unsinkable organic matter $S_{N S}$ in the $\mathrm{Ol}$ and Ofh horizons under the beech and fir stands is shown in Figure 2. The Ofh horizons in both stands are characterised by a higher share of unsinkable organic matter than the $\mathrm{Ol}$ horizons, with the highest share of $S_{N S}$ found in the Ofh horizons of the beech stands (average $28.6 \pm$ $5.3 \%)$. The average share of $S_{N S}$ in beech litter and in the $\mathrm{Ol}$ and Ofh horizons under the fir stands is: $6.1 \pm 1.1,0.2 \pm 0.1$ and $9.3 \pm 1.6 \%$ respectively.

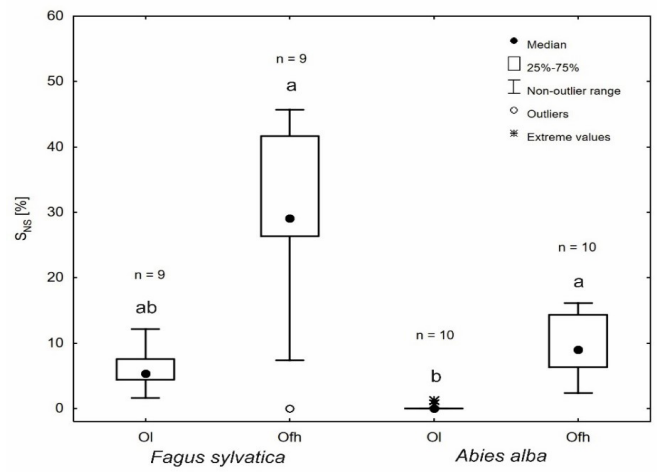

Figure 2 The range of variability of the percentage of unsinkable organic matter $S_{N S}$ in the $\mathrm{Ol}$ and Ofh horizons of the beech and fir stands. Different letters indicate the significance of differences between individual horizons (Kruskal-Wallis test, $p<0.05$ ) and $n$ is the sample size 


\section{The dynamics of water absorbability of or- ganic matter}

The dynamics of water absorbability of organic matter, presented in Figure 3, differs between the two species. In the case of beech litter, most of the organic matter sank during the first 24 hours of soaking, and an average of $89 \%$ of the matter sank after 2 days. In the case of fir litter, only $8 \%$ of organic matter sank during the first 24 hours while most of it $(25 \%)$ sank between the first and the second day of soaking. The largest amount of organic matter from the Ofh horizons of both species sank within the first $24 \mathrm{~h}$; in the case of beech stands it was an average of $19 \%$ while in the case of fir stands $46 \%$. An average of $21 \%$ of the organic matter of the beech Ofh horizons and $69 \%$ of the organic matter of the fir Ofh horizons sank after 2 days.

\section{The mean water absorption time}

The mean time $T_{A}$ of water absorption by organic matter being part of beech litter is 0.94 \pm 0.11 days (Fig. 4a) and is more than three times lower than the mean time $T_{A}$ reached by the organic matter of fir litter $(3.17 \pm 0.34$ days). The mean time $T_{A}$ reached by the organic matter of the beech Ofh horizons (3.22 \pm 0.29 days) is almost twice higher than time $T_{A}$ reached by the Ofh horizons of fir stands $(1.73 \pm 0.21$ days). Comparing the mean time of water absorption with the advancement of disintegration processes in the organic matter of individual horizons in the analysed stands (Fig. 4b), it can be concluded that in the case of fir ectohumus, time $T_{A}$ decreases with the growth of the $W_{N C}$ index, i.e. with the increase in the degree of organic matter decomposition. On the other hand, in beech ectohumus, the advancement of organic matter decomposition results in prolonging the time of water absorption by organic matter.

\section{Time of filling the internal capillarity of organic matter}

Figure 5 shows the cumulative percentage of organic matter sinking during the 14 days of soaking, and belonging to the $\mathrm{Ol}$ and Ofh horizons and the entire ectohumus $\mathrm{O}$, determined jointly for a total of 9 beech and 10 fir research plots. The percentage was used to determine the minimum soaking time $t_{\min }$ necessary to fill the internal capillarity of organic matter.

In the case of beech litter, time $t_{\text {min }}$ amounted to 1.2 days, by which it was over 3 days shorter than time $t_{\text {min }}$ reached by fir litter. The largest minimum time needed to fill the internal capillarity $(8.6$ days) characterises the organic matter of the beech Ofh horizons. This time is over 7 times greater than time $t_{\min }$ of the beech litter and 5.5 days longer than time $t_{\text {min }}$ reached by the organic matter of the Ofh horizons in fir stands. Time $t_{\text {min }}$ reached by organic matter in the entire beech ectohumus is only 1.4 days lower than time $t_{\text {min }}$ of fir ectohumus (Fig. 5). 

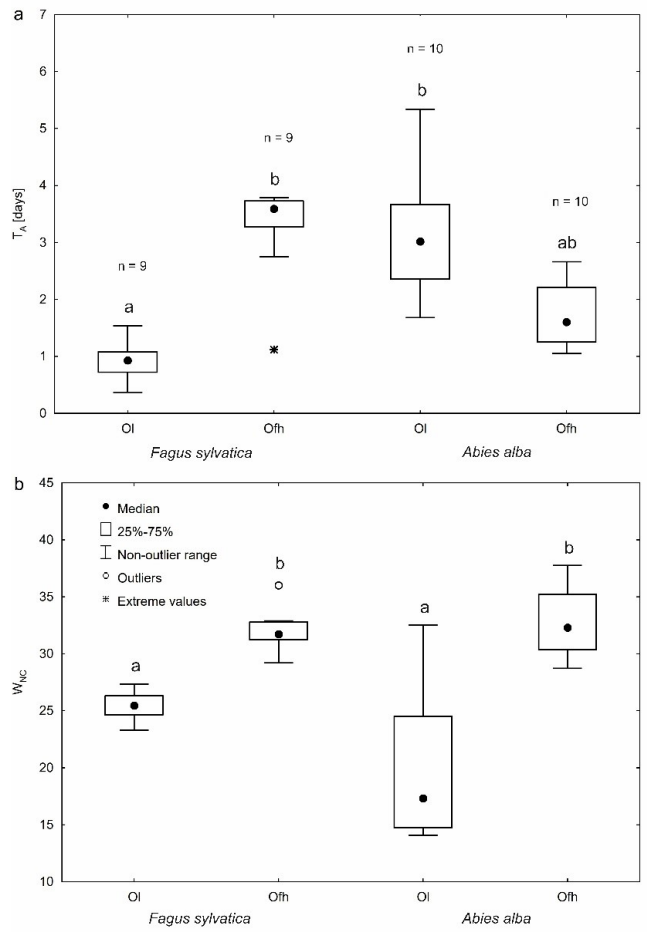

Figure 4 The range of variation of: a) the $T_{A}$ mean water absorption time and b) the $W_{N C}$ index of decomposition of the organic matter being part of the $\mathrm{Ol}$ and $\mathrm{Ofh}$ horizons in beech and fir stands. Different letters indicate the significance of differences between particular horizons (Kruskal-Wallis test, $p<0.05$ ) and $n$ is the sample size

\section{Discussion}

In their research on water absorbability in spruce stands (Picea abies (L.) H. Karst), Kucza \& Urbaś (2005) stated that the mean time of water absorption by the organic matter of the Ol, Of and Oh horizons amounts to 2.6, 1.7 and 0.9 days, respectively. They expressed the view that the time of water absorption can be a measure of the current state of organic matter decomposition. On the one hand, that thesis is confirmed by the results obtained in fir stands; on the other hand, it is undermined by the re-
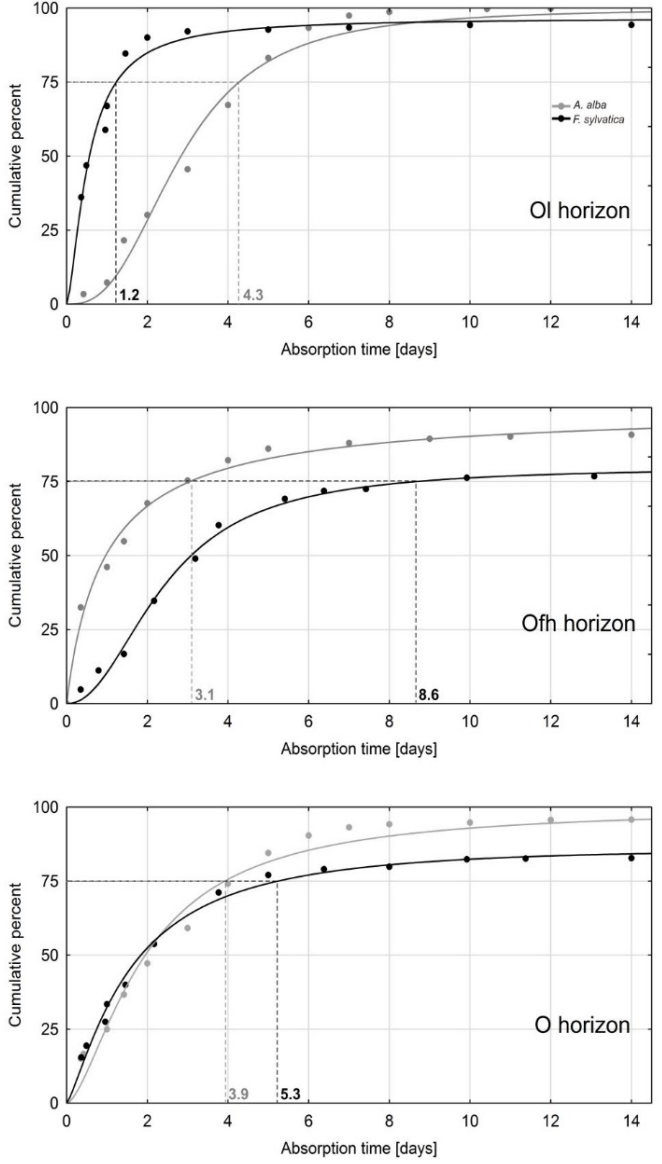

Figure 5 The cumulative percentage of organic matter sinking within 14 days of soaking along with the minimum time needed to fill the internal capillarity of the organic matter being part of the $\mathrm{Ol}$ and Ofh horizons and the entire organic horizons $\mathrm{O}$ of beech and fir stands

sults obtained in beech stands (Fig. 4). Despite a lack of differences between the values of decomposition index $W_{N C}$ in the $\mathrm{Ol}$ horizons of the fir and beech stands, water absorption processes in the organic matter of the litter of both species proceed in a different way. A similar pattern applies to the Ofh horizons (Fig. 3-5). This suggests that the water absorbability of organic matter is affected not only by the degree of decomposition itself but also by the 
accompanying multidirectional changes in the chemical composition of litterfall, and thus by the quality of organic matter.

The chemical composition of living plants translates into the quality of the litter they form (Berg \& McClaugherty 2008). Litter consists of plant remains containing various kinds of compounds soluble and insoluble in water. In general, these remains contain $15-40 \%$ cellulose, $10-43 \%$ hemicellulose, $25-40 \%$ lignins, $1-10 \%$ waxes and lipids and $1-15 \%$ protein (Schulze et al. 2005). Lignin is the most complex component of leaves, resistant to microorganisms (Gołąb 1978). According to Tomczuk (1975), beech leaves contain over 20\% lignins while fir needles contain about 23\%. Apart from the higher lignin content, fir litter is also characterised by a lower content of cellulose and hemicellulose than beech litter (Hobbie et al. 2006). The quality of litter translates into the rate of organic matter decomposition, dependent, among others, on the initial content of $\mathrm{N}, \mathrm{Ca}$, lignins as well as on the ratios: $\mathrm{C}: \mathrm{N}$, C:P and lignins to N (Fogel \& Cromack 1977, Jacob et al. 2010). Rutigliano et al. (1996) found different dynamics of lignin distribution in beech leaves and fir needles. In an early phase, lignin decomposed faster in beech than in fir whereas at a later stage the decomposition of lignin was faster in fir than in beech. The variation in the litter decomposition rate among different plant species is often positively correlated with the initial nitrogen content and negatively correlated with the initial lignin content (Hobbie et al. 2006). Comparing the rate of decay of beech and hornbeam leaves (Carpinus betulus L.), Gołąb (1978) found that the slower rate of beech leaf decomposition is related to a slower decomposition of hemicelluloses and lignins contained in them while the different resistance of these components to biological decomposition in both types of leaves results from differences in their chemical structure. A different rate of decomposition of individual components of litter makes its quality change over time, which continuously affects the course of the decomposition process
(Fioretto et al. 2005). The change in the quality of organic matter during the decomposition is indicated by the share of unsinkable organic matter (Fig. 2). While in fir stands the difference in the share of SNS between the $\mathrm{Ol}$ and Ofh horizons amounts to $9.1 \%$ on average, an increase in the average share of unsinkable organic matter from $6.1 \%$ (Ol horizon) to $28.6 \%$ (Ofh horizon) in beech stands indicates that the decomposition of beech organic matter produces compounds that are clearly hydrophobic, which results in a significant prolongation of the water absorption time (Fig. 4).

Differences in water absorption time between beech and fir litter may also result from differences in the age of needles and leaves that are its constituents. In beech stands, where leaves account for over $80 \%$ of the total litterfall in non-seed years and over $47 \%$ in seed years (Jonczak 2013), 80-90\% of the total annual litterfall occurs in October and November (Małek et al. 1998). Švidenko (1980) states that in fir stands $50-60 \%$ of litterfall are needles, which fall throughout the year with varying intensity: around $59 \%$ of needles fall in autumn, $18-23 \%$ in winter, $8-10 \%$ fall in spring and $9-13 \%$ in summer. Considering that fir needles remain on shoots from 2 to 11 years (Boratyński 1983) and that their falling lasts the whole year, the $\mathrm{Ol}$ horizons of fir stands may even contain needles from the last several years of litterfall, while in beech stands litter is composed of one-year-old leaves, fallen in a given year. As shown by Tomczuk (1975), the content of lignin in fir needles increases with the ageing of needles: in one-year-old needles it is $22.8 \%$ while in 3-year-old ones it is $25.9 \%$. The content of lignin in pine needles is also not uniform during the year: it is the highest in spring and the lowest in winter. Changes that occur in leaves during the growing season affect their wettability (Klamerus-Iwan \& Błońska 2017, Klamerus-Iwan \& Kraj 2017).

A different course of the dynamics of water absorbability of beech and fir organic matter can also be associated with the anatomical structure of the leaves of both species. The 
thickness of the cuticle, the amount of epicuticular and internal wax and the amount of pectin in the leaves are not only different in each plant species but also variable within a single plant itself, depending on its age, growth conditions and the side of a leaf (Hejnowicz 2002). The cuticle is a layer that is poorly permeable to water and air. It covers the whole epidermis, and the only breaks in the cuticle occur in places of the pores of stomata (Malinowski 1987), which after the death and fall of a leaf may be natural ways for water to enter the leaf interior. The stomata may be on the same level as other epidermis cells, but they may also be recessed below that level. The size and density of stomata depend on many factors, such as genetic conditions, age of needles/leaves and trees, and insolation (Franich et al. 1977, Hejnowicz 2002). Hypostomatic beech leaves have elliptical stomata (Cho et al. 2014), and their average size is $23.5 \mu \mathrm{m}$ (Denk 2003). According to Sweeney (2014), the width of stomata depends on the tree species; in Pinus sylvestris, Picea abies and Abies alba it is: 24.6, 33.1 and $25.9 \mu \mathrm{m}$, respectively. In fir, the stomata are recessed and the stomatal pores are covered with a wax crust (Bačić et al. 2005). The opening of the stomata is caused by an increase in turgor pressure in the stomatal cells which are penetrated by water. They have a mechanism that regulates the opening of pores depending on $\mathrm{CO}_{2}$ concentration and turgor inside the green organ (Hejnowicz 2002). While the mechanisms of stomata opening and closing are quite widely described in the literature, little is known about what happens to the stomata at the time of leaf fall. Considering that water scarcity causes a turgor decrease in stomatal cells and the closing of the stomata (Malinowski 1987), it may be expected that in the falling leaves/needles the stomata are closed. Nevertheless, as shown in Figure 6, presenting sample photographs of needle and leaf stomata from the $\mathrm{Ol}$ and Ofh horizons in both of the studied stands, the stomata of leaves in beech litter are open 28
(Fig. 6c) while in fragments of leaves from the Ofh horizons, the stomata are closed (Fig. 6d). Although at this stage of the research it is difficult to indicate the reason for these differences, the closed stomata in leaves from the Ofh horizon may impede the penetration of water into the leaf interior, which partly explains the prolongation of absorption time $T_{A}$ and time $t_{\min }$ along with the advancement of the degree of decomposition of beech organic matter (Fig. 4-5). On the other hand, the wax that covers needles (Fig. 6a), and presumably makes it more difficult for water to penetrate the interior of undecomposed needles, undergoes degradation with progressing decomposition (Fig. $6 b)$, which probably affects the acceleration of the water absorption rate and the decrease in time $T_{A}$ and $t_{\min }$ along with an increase in the degree of decomposition of fir organic matter.

Due to the large macroporosity of litter, depending on the size of organic particles in its composition (Ilek et al. 2017), water retention in this horizon occurs mainly through the

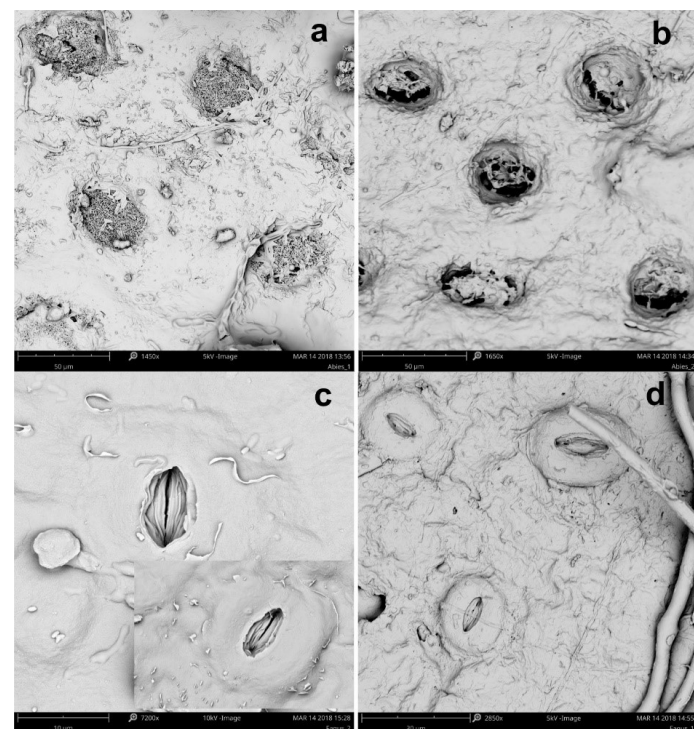

Figure 6 Samplephotographs of Abies alba Mill. needlestomatacovered with wax (a-b) and Fagus sylvatica L. leaves (c-d) collected from the $\mathrm{Ol}$ (a and c) and Ofh (b and d) horizons. 
adsorption and absorption of water through undecomposed organic matter. Zhang et al. (2006) found that the rate of water absorption by undecomposed litter of various types of stands decreases rapidly in the first 6 hours of soaking; and in the first 8 hours in the case of partially decomposed litter. In both cases, most of the water was absorbed in the initial period of soaking, and the influence of the type of stand on the absorption rate was hardly noticeable. Similar results were obtained by Zhang et al. (2009) and Chen et al. (2018). Considering that in those studies the absorption rate was examined for 20 or $24 \mathrm{~h}$ of soaking the samples in water, those results may mainly reflect the process of filling the outer capillarity (between particles), retaining water on the surface of organic particles, and only partially the process of filling their internal capillarity. This is indicated by the dynamics of water absorbability shown in Figure 3. While the majority of organic particles of beech litter and the Ofh horizons of fir stands soak within the first 48 hours, the dynamics of water absorbability of organic particles of fir litter and beech Ofh horizons is more spread over time. The fact of reaching a density greater than $1 \mathrm{~g} \cdot \mathrm{cm}^{-3}$ by organic particles does not mean the end of the absorption process, but only the moment of achieving a certain high degree of saturation of internal capillarity of particles (Kucza 2007). The period of internal capillarity filling is of great importance in the dynamics of water retention by organic horizons of forest soils. The minimum time $t_{\min }$, presented in Figure 5, indicates that despite the high porosity and low bulk density of the organic horizons of forest soils (Ilek et al. 2015), they can maintain the ability to retain water even in long-term rainfall. It should also be noted that despite the different dynamics of absorbability and different $t_{\min }$ values of in the $\mathrm{Ol}$ and Ofh horizons of the examined stands (Fig. 3 and 5), the cumulative percentage of organic matter sinking within 14 days, as determined for the $\mathrm{O}$ horizon, is similar in both stand types.

\section{Conclusions}

The research on water absorbability of beech and fir organic matter has shown that filling the internal capillarity of organic particles with water is a complex process that depends on many factors. It has been confirmed that water absorbability is influenced by the botanical origin of organic particles and the degree of their decomposition. In fir stands, the time of water absorption decreases with an increase of the decomposition index, while in beech stands an increase in the advancement of decomposition processes results in a prolonged time of water absorption by organic matter. A similar pattern applies to the minimum time necessary to fill internal capillarity. The dynamics of water absorption of organic matter, distributed over time, indicates that no single rainfall is able to entirely fill the internal capillarity of organic particles, whereby the organic horizons of forest soils can maintain the ability to retain water even in longterm rainfall. The knowledge of the influence of species composition on retention properties of the organic horizons and the dynamics of their rainwater retention may contribute to better management of the forest environment and to an awareness of how to affect it, thereby increasing the retention abilities of a catchment.

\section{Acknowledgements}

This research was financed by the Ministry of Science and Higher Education of the Republic of Poland.

The results presented in this paper have been partly referenced at the VIII International Agriculture Symposium "AGROSYM 2017" in Jahorina (Bosnia and Hercegowina, 2017).

The authors thank anonymous reviewers for their many helpful suggestions. 


\section{References}

Bačić T., Krstin L., Roša J., Popović Ž., 2005. Epicuticular wax on stomata of damaged silver fir trees $(A b$ ies alba Mill.). Acta Societatis Botanicorum Poloniae 74(2):159-166. DOI: 10.5586/asbp.2005.021

Berg B., McClaugherty C., 2008. Plant litter - decomposition, humus formation, carbon sequestration. Springer-Verlag, Berlin, Germany, pp. 11-34.

Boratyński A, 1983. Systematyka i geograficzne rozmieszczenie. In: Białobok S. (ed.), Jodła pospolita Abies alba Mill. Nasze drzewa leśne 4. PWN, Warszawa-Poznań, pp. 41-85.

Chen S., Cao T., Tanaka N., Gao T., Zhu L., Zou C.B., 2018. Hydrological properties of litter layers in mixed forests in Mt. Qinling, China. iForest 11: 243-250. DOI: 10.3832/ifor2535-011

Cho S.H., Jeong K.S., Kim S.H., Pak J.H., 2014. Leaf cuticle micromorphology of Fagus L. (Fagaceae) species. Journal of Asia-Pacific Biodiversity 7: 378-387. DOI: 10.1016/j.japb.2014.10.002

Denk T., 2003. Phylogeny of Fagus L. (Fagaceae) based on morphological data. Plant Syst. Evol. 240: 55-81. DOI: $10.1007 / \mathrm{s} 00606-003-0018-\mathrm{x}$

Dziadowiec H., Pokojska U., Prusinkiewicz Z., 2004. Materia organiczna, koloidy i roztwór glebowy jako przedmiot badań specjalistycznych. In: Bednarek R., Dziadowiec H., Pokojska U., Prusinkiewicz Z. (eds.) Badania ekologiczno-gleboznawcze. Wyd. Nauk. PWN, Warszawa, pp. 113-246

Fioretto A., Di Nardo C., Papa S., Fuggi A., 2005. Lignin and cellulose degradation and nitrogen dynamics during decomposition of three leaf litter species in a Mediterranean ecosystem. Soil Biology and Biochemistry 37(6): 1083-1091. DOI: 10.1016/j.soilbio.2004.11.007

Fogel R., Cromack K., 1977. Effect of habitat and substrate quality on Douglas fir litter decomposition in western Oregon. Canadian Journal of Botany 55(12):16321640. DOI: 10.1139/b77-190

Franich R.A., Wells L.G., Barnett J.R., 1977. Variation with tree age of needle cuticle topography and stomatal structure in Pinus radiate D. Don. Annals of Botany 41(3): 621-626. DOI: 10.1093/oxfordjournals.aob. a085331

Gołąb Z., 1978. Chemical changes occurring in beech and hornbeam leaves in their decomposition course in natural conditions. Soil Science Annual 29: 31-41.

Greiffenhagen A., Wessolek G., Facklam M., Renger M., Stoffregen H., 2006. Hydraulic functions and water repellency of forest floor horizons on sandy soils. Geoderma 132: 182-195. DOI: 10.1016/j.geoderma.2005.05.006 DOI: 10.1016/j.geoderma.2005.05.006

Hobbie S.E., Reich P.B., Oleksyn J., Ogdahl M., Zytkowiak R., Hale C., Karolewski P., 2006. Tree species effects on decomposition and forest floor dynamics in a common garden. Ecology 87(9): 2288-2297. DOI: 10.1890/0012-9658(2006)87[2288:TSEODA]2.0.CO;2

Ilek A., Kucza J., Szostek M., 2015. The effect of stand species composition on water storage capacity of the organic layers of forest soils. European Journal of Forest Research 134: 187-197. DOI: 10.1007/s10342-0140842-2

Ilek A., Kucza J., Szostek M., 2017. The effect of the bulk density and the decomposition index of organic matter on the water storage capacity of the surface layers of forest soils. Geoderma 285: 27-34. DOI: 10.1016/j.geoderma.2016.09.025

IUSS Working Group WRB, 2015. World Reference Base for soil resources 2014. International soil classification system for naming soils and creating legends for soil maps. Update 2015. World Soil Resources Reports 106. FAO, Rome.

Jacob M., Viedenz K., Polle A., Thomas F.M., 2010. Leaf litter decomposition in temperate deciduous forest stands with a decreasing fraction of beech (Fagus sylvatica). Oecologia 164(4): 1083-1094. DOI: 10.1007/ s00442-010-1699-9

Jonczak J., 2013. Dynamics, structure and properties of plant litterfall in a 120 -year old beech stand in Middle Pomerania between 2007-2010. Soil Science Annual 64(1): 8-13. DOI: 10.2478/ssa-2013-0002

Klamerus-Iwan A., Błońska E., 2017. Seasonal variability of interception and water wettability of common oak leaves. Ann. For. Res. 60(1): 63-73. DOI: 10.15287/ afr.2016.706

Klamerus-Iwan A., Kraj W., 2017. Wettability and interception in relationship with the seasonal changes on the Fagus sylvatica leaf surface. Forest Research Papers 78(3): 210-217. DOI: 10.1515/frp-2017-0023

Kucza J., 2007. Właściwości hydrologiczne materii organicznej gleb leśnych na przykładzie gleb pod świerczynami istebniańskimi. Zesz Nauk AR Krak, Ser Rozpr 442, pp. 44-65.

Kucza J., Urbaś J., 2005. Water absorption of organic matter taken from horizons of ectohumus of forest soils under Norway spruce stands. EJPAU Forestry 8(4): 50-58.

Laurén A., Mannerkoski H., 2001. Hydraulic properties of mor layers in Finland. Scand. J. For. Res. 16: 429-441. DOI: $10.1080 / 02827580152632829$

Malinowski E., 1987. Anatomia roślin. Wyd. Naukowe PWN, Warszawa, pp. 63-84.

Małek S., 2006. Struktura i dynamika opadu organicznego w drzewostanie bukowym na powierzchni monitoringowej w Ojcowskim Parku Narodowym w latach 19952000. Leśne Prace Badawcze 3: 71-82.

Małek S., Wężyk P., Neroj B., 1998. Struktura i dynamika opadu organicznego drzewostanu bukowego w różnych wariantach żyzności siedliska w Ojcowskim Parku Narodowym w latach 1995 i 1996. Acta Agr. Silv. ser Silv. 36: 63-76.

Niewinna M., 2010. Litter fall and rate of decomposition in selected tree stands of the Bieszczady Mts. Roczniki Bieszczadzkie 18: 59-73.

Onda Y., Yukawa N., 1994. The influence of understories and litter layer on the infiltration of forested hillslopes. In: Proceedings of the International Symposium on Forest Hydrology. Tokyo, Japan, pp. 107-114. 
Putuhena W.M., Cordery I., 1996. Estimation of interception capacity of the forest floor. Journal of Hydrology 180: 283-299. DOI: 10.1016/0022-1694(95)02883-8

Rutigliano F.A., De Santo A.V., Berg B., Alafani A., Fioretto A., 1996. Lignin decomposition in decaying leaves of Fagus sylvatica L. and needles of Abies alba Mill. Soil Biology and Biochemistry 28(1): 101- 106. DOI: 10.1016/0038-0717(95)00120-4

Sharafatmandrad M., Bahremand A., Mesdaghi M., Barani H., 2010. The role of rainfall and light interception by litter on maintenance of surface soil water content in an arid rangeland (Khabr National Park, southeast of Iran). DESERT 15: 53-60.

Schulze W.X., Gleixner G., Kaiser K., Guggenberger G., Mann M., Schulze E.D., 2005. A proteomic fingerprint of dissolved organic carbon and soil particles. Oecologia 142: 335-343. DOI: 10.1007/s00442-004-1698-9

Suliński J., 1993. Modelowanie bilansu wodnego w wymianie między atmosferą, drzewostanem i gruntem przy użyciu kryteriów ekologicznych. Zesz Nauk AR Krak Ser Rozprawy 179, pp. 15-20.

Sweeney C.A., 2004. A key for identification of stomata of the native conifers of Scandinavia. Review of Palaeobotany and Palynology 128: 281-290. DOI: 10.1016/
S0034-6667(03)00138-6

Švidenko A.J., 1980. PichtovyelesaUkrainy. Izdat. pri Lvov. Gosud. Univ Lvov.

Tamai K., Abe T., Araki M., Ito H., 1998. Radiation budget, soil heat flux and latent heat flux at the forest floor in warm, temperate mixed forest. Hydrological Processes 12: 2105-2114. DOI: 10.1002/(SICI)10991085(19981030)12:13/14<2105::AID-HYP723>3.0. $\mathrm{CO} ; 2-9$

Tomczuk R.I., 1975. Chemical composition of wood. Folia Forestalia Polonica Seria B 12: 5-14.

Walsh R.P.D., Voigt P.J., 1977. Vegetation litter: an underestimated variable in hydrology and geomorphology. Journal of Biogeography 4: 253-274. DOI: $10.2307 / 3038060$

Zhang Z., Chen Y., Zhang Z., Cui H., Lei Y., Wang D., Sui J., 2006. Water-holding characteristics of litter in different forests at the Lianxiahe watershed. Front. For. China 4: 413-418. DOI: 10.1007/s11461-006-0046-0

Zhang Z., Lei Y., Su K., Wang G., Wang D., Ma H., 2009. Hydrological characteristics of litter in different forest succession stages at Liuxihe Watershed, southern China Front. For .China 4(3): 317-322. DOI: 10.1007/s11461009-0053-z 
